\title{
Yönetim Anlayışı ve Metodolojisi Açısından Karl R. Popper ve Viyana Çevresi
}

\author{
Karl R. Popper and Vienna Circle in Respect of the Understanding of Government and \\ Methodology
}

\section{Hüsamettin iNAÇ}

Prof. Dr., Dumlupınar Üniversitesi, IiBB, Siyaset Bil. ve Ulus. Iliş̧kiler husamettininac@yahoo.com

https://orcid.org/0000-0002-6922-2010

\section{Hakkı EVCiM}

Bilim Uzmanı, Afyon Kocatepe Üniversitesi, SBE, Sosyoloji YL. Prog. Mezunu

hevcimhk@hotmail.com

\author{
Makale Başvuru Tarihi / Received: \\ 03.12.2020 \\ Makale Kabul Tarihi / Accepted: \\ 27.12.2020 \\ Makale Türü / Article Type: Araştırma \\ Makalesi
}

\section{ÖZET}

Karl R. Popper epistemoloji alanında yaptığı çalışmalarla 21. yüzyılın en tanınmış filozoflarından biridir. Popper' ın felsefe anlayışı ve felsefe problemlerine getirmek istediği çözümler üzerinde durmak istenirse, onun felsefe çalışmalarına başladığı yıllarda ortaya çıkan Viyana çevresi felsefe ekolününde de dikkate alınması gerekir. Çünkü Viyana çevresinin felsefi görüşleriyle Popper'ın felsefe görüşleri arasında karşıtlığın getirdiği bir etkileşme vardır. Bu metinde, Popper'ın metodolojisinden bahsederken öncelikle Viyana çevresi yaklaşımı, daha sonra Popper'ın eleştirel yöntemi, Popper'ın yanlışlanabilirlik ilkesi ve Popper'ın yönetim modelini oluşturan üç dünya kuramı ele alınmıştır.

Anahtar Kelimeler: Yönetim Modeli, Üç Dünya Kuramı, Viyana Çevresi, Eleştirel Teori, Yanlışlanabilirlik Ilkesi

\section{ABSTRACT}

Karl R. Popper is one of the very known theorists and philosophers of the 21th century with his studies focused on the epistomology. It is apparently seen that his understanding of philosophy and his approach towards the governmental issues and the political thought derived from the Vienna Circle. There are smooth correlations among the critical opinions of the Vienna Circle and the controversial thoughts of Karl R. Popper. In this paper, we elaborated the methodology of Karl Popper, his attitude towards against the Vienna Circle, his critical theory of government and his original governmental understanding called as "three world view" as well as with his refutability principle.

Keywords: Government Model, Three World Theory, Vienne Circle, Critical Theory, Refutability Principle 


\section{GiRiş}

Karl R.Popper epistemoloji alanında yaptığı çalışmalarla 21. yüzyılın en tanınmış filozoflarından biridir. Popper' ın felsefe anlayışı ve felsefe problemlerine getirmek istediği çözümler üzerinde durmak istenirse, onun felsefe çalışmalarına başladığı yıllarda ortaya çıkan Viyana çevresi felsefe ekolünde de dikkate alınması gerekir. Çünkü Viyana çevresinin felsefi görüşleriyle Popper'ın felsefe görüşleri arasında karşıtlığın getirdiği bir etkileşme vardır (Popper, 1985:8).

Bu metinde, Popper'ın metodolojisinden bahsederken öncelikle Viyana çevresi yaklaşımını, daha sonra Popper'ın eleştirel yöntemini, Popper'ın yanlışlanabilirlik ilkesini ve Popper'ın üç dünya kuramını ele aldık.

Eleştirel akılcılığın kurucusu Karl Raimund Popper 28 Temmuz 1902'de Viyana'da doğdu. 1918'de Viyana Üniversitesinde özel öğrenci olarak felsefe, psikoloji, tarih, matematik, Fizik derslerini almış ve 1928 yılında dil kuramcısı Karl Böhler'in danışmanlığında doktorasını tamamlamıştır. Nazilerin Avustralya'ya işgalinden önce 1937 yılında Yeni Zelanda'ya giderek burada Cantebury üniversitesinde doçent oldu.1945 yılında İngiliz vatandaşı oldu. Burada mantık ve bilimsel yöntem profesörü olarak çalıştı. Kraliçe 2. Elizabeth tarafından 1965 yılında 'sir' unvanı verildi. 17 Eylül 1994'te Londra'da öldü.

K.Popper 1920'li yıllarda etkili olan Viyana çevresi tarafından temsil edilen "Mantıksal pozitivizm"e eleştiriler yöneltmiş ve bu yüzden Viyana çevresince dışlanmıştır.

"Bilimsel yöntem, sınırlandırma ayracı ve tümevarım sorunu hakkındaki görüşlerini "Bilimsel Araştırmanın Mantığı" adıyla kaleme alan Popper bu yapıtında; Einstein'ın yeni çekim kuramı'na bilimin işleyişine, bilimsel bilginin yapısına ilişkin olarak daha önce söylenenlerin tümünün yanlışlığını ortaya koymayı amaçlamıştır (Popper, 2005:17)." Doğal yasaları aramak çoktandır - en azından Newton'dan beri - bilimin esas görevi olarak görülmüştür. Fakat bilginlerin bu yolla nasıl hareket etmeleri gerektiğini, sistemli bir biçimde ilkin Francis Bacon anlatmıştır. Bacon'ın bu süreci formülleştirişi, onun zamanından bu yana bir hayli değişikliğe uğratılmış, inceltilmiş ve karmaşıklaştırılmış olmakla birlikte, onun öncülük ettiği çizgide bir betimleme, on yedinci yüzyıldan yirminci yüzyıla hemen hemen bütün bilimsel kafalı insanlar tarafından kabul edilmiştir (Magee, 1982:17-18)."

Karl Popper, deneysel bilimlerde tümevarım yöntemine karşı çıkmıştır. Bilim felsefesinde D. Hume'un ortaya attığı varsayımın üst üste yapılan gözlemlerle aynı sonucu vermesi yani tümevarım metodunun aslında doğru bilgiyi vermediği bilgisi vermediği düşüncesi uzun yıllar 
çözülmeyi bekleyen sorun olarak kalmıştır. Hume, A olayının tekrarında sürekli B olayının olması ve yine A olayı olduğunda da bizim B olayını beklememiz mantıkı bir sonuç değil, psikolojik bir sonuçtur şeklinde bir açıklama yapar. Ona göre varsayımın "tüm"e tekabül etmesi için sonsuz sayıda deney yapılması gerekir. Popper bunun yerine tümdengelim yöntemiyle ve yanlışlanabilirlik ölçütü ile söz konusu varsayımın geçerlilik kazanabileceğini ileri sürmüştür. Popper bu yönüyle Viyana çevresi düşüncesinin karşısında yer almıştır.

\section{VIYANA ÇEVRESI}

“Mantıksal pozitivizm, 20.yy’ın önemli felsefe akımlarından biri oluşmuştur. Bu akımı Viyana Çevresi adından ayrı düşünmek olanağı yoktur. Çevre, 1922'de Viyana Üniversitesi Felsefe Profesörlüğüne atanan Moritz Schlick' in, yanında kendisi gibi öncelikle bilim adamı olarak yetişmiş düşünürleri toplayarak, tartışmalar yoluyla bilime ve ödün vermez bir deneyciliğe ağırlık veren bir yaklaşım kurma çabaları sonucunda doğmuştur. Schlick'ten başka önem taşıyan çevre üyeleri, Neurath, Viyana'da uzun süre kalmamış olan Carnap ve felsefeciden çok mantıkçı ve matematikçi olan Gödel'dir (Denkel, 1997:306)."

Aydınlanma gelişen bilimsel devrim 19. yüzyıla gelindiğinde artık sadece elle tutulan, gözle görülen bir bakış açısıyla bilimi tanımlama noktasına gelmiştir diyebiliriz.

"Mantıksal pozitivizmde bir hükmün bilgi ifade edebilmesi için iki şartı yerine getirmesi gerekir:

1-Hüküm iyi bir şekilde formüle edilmiş olmalıdır; yani gramer açıdan (mantıksal olarak) doğru olmalıdır.

2-Hüküm, empirik olarak sınanabilmeli yani tasdik edilebilmelidir.

$\mathrm{Bu}$ şartları yerine getirmeyen hükümler bilgi ifade etmezler. Kavrayışsal açıdan (epistemolojilik yönden) anlamsızdırlar. Ahlaki, dini ve metafiziksel hükümler -'Kimseyi öldürmeyeceksin', 'Tanrı sevgidir', 'Madde birdir'- kavrayışsal anlam için geçerli bu pozitivist ölçütlere göre kavrayışsal olarak anlamsızdır. Bu hükümler anlam ifade etmezler. Böylesi hükümlerin duygusal olarak anlamlı oldukları tabii ki inkâr edilemez. Örnek olarak değer yargıları, hem birey hem de toplum için genelde çok büyük anlam taşır. Bu teze göre asıl mesele bu hükümlerin bilgi sunmadıklarıdır (Skirbekk ve Gilje, ty.:541)."

1920 'li ve 30'lu yıllarda oldukça etkisini hissettiren Viyana çevresi, bilginin sağlam bir temel üzerinde inşası ve buna ölçüt; anlamlılık ve doğrulanabilirlik ilkesinin savunulması üzerine yaklaşımlarını ortaya koymuştur. Bu yüzden özellikle metafiziğe karşı olmuşlardır diyebiliriz.

"İşte bu kaynakları temel alan mantıksal pozitivistler bir anlamda, felsefeyi bilime indirgemeye çalışmışlardır. Metafiziğin dile getirdiği önermeleri anlamsız sayabilecek formülü, anlam kavramı olarak benimsedikleri doğrulama ilkesinde bulmuşlardır. Bu ilkeye göre "bir önermenin anlamı, onun doğrulanabilir olmasıdır". Doğrulama ya da doğrulanabilirlik, doğruluk yada yanlışığın deneysel gözlemde saptanması yada kanıtlanması olduğuna göre örneğin "Töz nitelikleri bir arada tutan ilkedir" ya da "Tin kendini tarihsel 
süreç içinde gerçekleştirir" gibi önermeler düpedüz anlamsızdır. Bunları konu eden söylem, yazılar, kitaplar saçmalığı aşamazlar" (Denkel, 1997:307).

Viyana çevresine göre bilimsel önermelerin aynı zamanda gözlem diliyle ifade edilebilmesi gerekir. “Bu inançları ise en büyük desteğini Ludwig Wittgenstein'nın Tractatus Logico Philosophicus adlı kitabından almıştır. Wittgenstein mantıksal pozitivistlerin görüşlerini kitabında "dil gerçeğin resmidir" şeklinde dile getiriyordu. Viyana grubu, bu dil teorisini hemen benimsemiş, Tractatus' u mantıksal pozitivizmi temellendiren önemli bir gelişme olarak değerlendirmiştir. Tractatus' tan aldıkları destekle Viyana grubu matematiksel eş sözler (tautology) dışında, bütün bilginin deney yoluyla doğrulanması gerektiğini bir kez daha vurgulamak olanağı bulmuştur (Sunar, 1999:107-108)."

\section{POPPER'IN ELEŞTIREL YÖNTEMI ve YANLIŞLANABILIRLIK ILKESI}

Mantıkçı pozitivizmin bilim anlayışı karşısında olan iki düşünür dikkati çekmektedir. Bunlardan birisi Wilhelm Dilthey diğeri ise Karl Popper' dır.

Popper, bilimin gelişim serüveninde her dönemin kendine özgü olduğunu ve bir sonraki aşama için gerekli olduğunu savunur. Dolayısıyla Antik Yunan öncesi doğa olaylarına o dönemde getirilen mitolojik açıklamaları yerinde bulur. Fakat Antik Yunan dönemi ile birlikte aklı eleştirme süreci başlamıştır.

"Popper tüm yaşamı boyunca eski Yunana duyduğu özel minnettarlığı ifade etmesinin mantığında insan bilgisinin temelinde "Eleştirel aklın" yerleştirilmesi arzusu yatmaktadır. Popper, "Eski Yunan kuşkusuz daha başlarında olduğumuz temel bir devrimin kökeninde yer almaktadır" Sokrates ve Perikles' in Eski Yunan'ı eski söylemler karşısında aldıkları sorgulayıcı tavırla "eleştirel geleneğe" yol açmışlardır; liberal felsefenin ve bilimsel gelişmenin iç içe geçtiği ilk topraktır burası (Boudouın, 1993:21)." der.

Aslında Popper'e göre dünyayı anlamak için birçok yöntemden bahsedilir. Mevcut probleme göre yöntemler de değişebilir. Bu yöntemler arasında en kayda değer yöntemin ise aynı zamanda felsefenin de esası olan eleştirel yöntemdir.

Popper'a göre bilimin çıkış noktası algı, gözlem deney değildir. Bilgi ancak bir problem ortaya çıktığında ve bu problem karşısında arayışa girmemiz ile ortaya çıkmaya başlar. Buna göre mevcut kavramlarla sorgulamaya başlarız. Sorunu çözemeyince yanlış olan bu kavram terk edilecek eleştirel bir tavırla yeni çözüm yolları bulmaya çalışırız. Böylece bu problem karşısındaki eleştirel arayışımız yeni bilgiyi ortaya çıkarır. Buradan hareketle bilimin gelişim seyrinde her bir dönem bir sonrakinin hazırlayıcısı olmuştur. Doğa olaylarına mitolojik açıklama getirilmeseydi Antik Yunan felsefesi olmazdır. Aydınlanmada bir önceki döneme eleştirel bir tarzda sorgulamanın yapılmasıyla ortaya çıkmıştır. Bu süreç bu şekilde devam eder. Burada önemli olan eleştirel yöntemi her zaman canlı tutmaktır. Ayrıca dikkat edilmesi gereken diğer husus ise elde edilen yeni bilginin de eleştirilerle çürütülebilmesinin mümkün olmasıdır. Bir teorinin yanlışlanabilirliği mümkünse eğer o zaman teori geçerlidir. Popper'a göre bu yaklaşım felsefeden politikaya kadar değişik alanlarda uygulanabilir. Popper'a göre 
asla değişmez doğruluk söz konusu değildir. "Popper'ın doğruluk sorununa ilişkin yazıları, doğruluk kavramının tanımı, doğruluk ölçütü yada doğruluğun uygunluk olup olmadığı konularından çok, doğrulanabilirlik, yanlışlanabilirlik üzerinde odaklaşır. Ama onun için doğruluk, temelde uygunluktur. Bu kavram Popper tümcelerin önermelerin doğruluğundan çok kavramların doğrulanabilirliği veya yanlışlanabilirliği ile ilgilidir. Ancak olgularla uygun düşüyorsa doğrudur (Tepe, 2003:128)."

"Popper'a göre “Bilim, yanlışlanabilir hipotezler geliştirilerek bilgiyi ilerletme amacına yönelen bir uğraştır. Her bilimsel kuram yanlışlamayı beklemek durumundadır. Tümevarımcı bir önermenin doğrulanması olanaksız yanlışlanması deneysel açıdan kolay olduğuna göre, bilimsel kurallar deneysel sınamaya dolayısıyla reddedilmeye hazır oldukları ama henüz reddedilmedikleri sürece geçerli kabul edilebilirler (Çelebi, 1996:73)."

“Popper Mantıkçı Pozitivizmin doğrulanabilirlik ilkesine karşı çıkar. Schlick ve Waismann'ın bir ifadenin anlamını ya da bilimselliğini doğrulanabilirliğine dayandıran tezlerini eleştirir. Bunun yerine bir sistemin deneysel olarak kabul edilebilir olmasına, onun deneyle sınanabilirliğine dayandırır. Bu ise, onu "sınırlandırma ölçütü"olarak doğrulanabilirliğin yerine yanlışlanabilirliğin konulması düşüncesine götürür. Burada Popper' ın dayanak noktasını oluşturan şey, genel tümcelerin mantıksal biçimleriyle bağlantılı olan doğrulanabilirlik ile yanlışlanabilirlik arasındaki bakışımsızlıktır. Kuramsal tümcelerin saltık doğrulanması olanaksız olduğu halde yanlışlanması olanaksız değildir. Bu nedenle Popper'a göre doğrulanabilirlik ölçütü yerini yanlışlanabilirliğe bırakmak durumundadır. Yanlışlanabilir olma ya da yanlışlanabilirliğe açık olma "bilimselliğin" ölçütü diye görülebilir. Gelecekte yanlışlanabilme olanağını taşıyan her tümce, işte bu nedenle bilimsel bir tümce olmaktadır (Tepe, 2003:128)."

Popper tümevarımsal bakış açısına yönelttiği eleştirileri birkaç noktada toplayabiliriz. Popper Viyana Çevresinin mantıkçı deneyciliğine karşı tavır alarak "olasılıktan” söz etmiştir.

- Öncelikle, gerçeğin dolaysız gözlemini savunan "tümevarımcı"iddiaya karşı çıkmış ve bunun yerine tahminde bulunma etkinliğinin önceliği düşüncesini öne çıkarmıştır.

- Daha sonrada bilme sürecinde metafiziğin elenmesi gerektiğini savunan "olgucu" (pozitivist) sava cephe almış ve metafiziğin, tahminlerin oluşmasında veya kuramların inşasında rolü olabileceğini öne sürmüştür (Boudouın, 1993:30)."

Popper, mevcut bir önermenin olasılığının olacağını, yeni ortaya atılan önermenin de olasılığı olacağını ve bu durumun hep böyle devam edeceğine belirtir. Burada hareketle Popper'ın düşüncesinde ana unsurların "tahmin etme" ve "reddetme" olduğunu ve bilimsel bilginin bu unsurlar çerçevesinde geliştiğini söyleyebiliriz. Bu durumu, Illkay Sunar'ın Magee'den aktardığı alıntı ile daha iyi özetleyebiliriz.

"Newton fiziği gelmiş geçmiş en başarılı ve önemli bilimsel teoriydi. Gözlenebilen dünyada her şey bu teoriyi doğruluyordu. ìki yüzyıl boyunca onun ortaya koyduğu yasalar yalnız gözlem ile değil, faydalı sonuçlarıyla da kanıtlanmıştır - bu yasalar Batı bilim ve teknolojisinin temeli olmaktan başka birçok şey hakkında, yeni gezegenlerin varlığından tutunuz da, med 
ve cezir, makinelerin işlemeleri ile ilgili olarak kesin öndeyilerde bulunabiliyordu. Eğer dünyada bilgi diye bir şey varsa, Newton sisteme o bilgiydi: insanlığın elde ettiği en kesin ve güvenilir bilgi sistemi buydu. Eğer bilimsel yasalar içinde Doğa Yasaları olarak, tümevarımsal bir şekilde, doğrulanan bir yasa varsa, o da milyarlarca gözlem ve deneye dayanarak doğrulanan Newton yasalarıydı... Fakat bütün bunlara rağmen, yirminci yüzyılın başında Newton'un teorisinden farklı bir teori Einstein tarafından öne sürüldü... Herkes yanılmıştı, bilinmeyen olguların da Newton sistemini kanıtlamayacağına dair inançları yanlış çıkmıştı. Ama nasıl olurdu, bir uygarlığın uzun bir dönemi bu sisteme dayandırımış ve büyük pratik yarar sağlamıştır. Eğer bu kadar olgu ve tümevarımsal destek bir teoriyi doğrulamıyorsa, o zaman ne doğrulayabilirdi? Işste Popper hiçbir şeyin bir teoriyi mutlak olarak doğrulamayacağını görmüştür. Geçerli bir teori hakkında söylenebilecek en kesin şey, o teorinin o güne kadar yapılmış gözlemler tarafından desteklenmiş olduğundan ibarettir (Sunar, 1999:2119)."

Popper kendi düşüncelerinin şekillenmesinde Einstein'ın relativ teorisindeki açıklamaları etkili olmuştur. Einstein kendi teorisini oluştururken ortaya attığı önermenin hangi şartlar altında geçersiz kalabileceğini önceden açıklamıştır. 1919 yılında yapılan gözlemler neticesinde ışığın, gök cisimlerinin etkisi altında kaldığında saptığı gözlemlenmiştir. Bu olay Einstein'ın eklediği bir olay idi. Yani kendi teorisi yanlışlanmıştır. Popper bu açıklamalardan ve sonrasında yaşanan gelişmelerden etkilenmiştir. Popper'a göre bilimsel önermenin doğrulanabilir olmasından çok yanlışlanabilir olması ön plana çıkmaktadır.

"Şüphesiz bilimsel teorilerin, olgularla uygunluk içinde olmaları, olgular tarafından doğrulanabilmeleri de gerekir. Fakat bir teorinin bilimsel olma niteliği kazanabilmesi için, bu teorinin mevcut veya mümkün bir olgu tarafından yanlışlanmaya açık olması - Popper'ın deyimiyle - potansiyel olarak yanlışlanabilir olması gerekir. Nitekim bazı teoriler olaylarla uygunluk içinde görülebilirler; bu teorileri savunanlar, teorilerinin olup - biten hadiseleri açıkladığına inanırlar. Bu gibi teorileri yanlışlama imkânı yoktur. Popper bu gibi teorilere Marksizmi, Freud ve Adler'in görüşlerini örnek alarak göstermektedir. Bu gibi teoriler çerçevesinde teoriyi çürütebilecek bir olgu tasarlamak mümkün değildir. Çünkü gözlenen her hadisenin teori tarafından ön görüldüğü ve teoriye uyduğu kabul edilir. Bu bakımdan bilimsel olmanın ölçüsü olaylarla uygunluk yani doğrulanabilirlik değil, olgular tarafından çürütebilirlik veya yanlışlanabilirlik olarak alınmalıdır (Popper, 1985:10)."

Popper'da doğrulanabilirlik ilkesinin ölçüt olarak alınması, bu ilkenin mantık olarak tümevarıma dayanması nedeniyle uygun görülmez. Çünkü tümevarım evrensel önermeleri ifade ettiğinden ve "tüm"ün bütün öğelerini kapsadığından anlamsızdır. İleri sürülen tümevarımsal önerme bütünün tamamını kapsadığı varsayılsa da, bu önerme, geleceğe ilişkin açıklamalarda bulunamaz. Çünkü gelecek ile gözlem yapmak imkânsızdır.

"Popper tümevarım sorununu "yanlışlama" mantığı ile çözmeye çalışmıştır. Nedensellik ve tümevarım sorunları Hume'dan bu yana, birçok doğa bilimcisini rahatsı eden, hatta bazılarını dinsel inançlara doğru iten sorunlardı. Popper yanlışlama (falsification) mantığı ile Hume' un dile getirdiği tümevarım sorununu kesin bir çözüme ulaştırdığına inanmıştır. 
Popper'ın öne sürdüğü çözüm görünürde oldukça basittir; bir teori (veya genelleme) ne kadar doğrulanırsa doğrulansın, yanlışlanamayacağı kanıtlanamaz. Örneğin "bütün kuğular beyazdır" genellemesi mutlak bir genelleme olarak kanıtlanamaz; fakat tek bir siyah bir kuğunun varlığı bu genellemenin kesin olarak yanlışlanabilmesi için yeterlidir. Başka bir deyişle, doğrulama olasılığa dayandığını halde, yanlışlama kesin ve mutlaktır (Sunar, 1999:2728)."

Popper, yapılan gözlemlerden hareketle genel önermelere ulaşmanın imkânsızlığını, doğrulanabilirlik ilkesi doğrultusunda evrensel önermelere ulaşma gayreti içinde olunduğunu belirtmektedir. "Ancak özel önermelerden - ne kadar çok olursa olsun - varılan evrensel önermelerin mantıksal açıdan doğruluğunu tanıtlamak mümkün değildir. Böyle bir çıkarım her zaman yanlış olabilecektir: kuğuların beyaz olmalarına ilişkin ne kadar çok gözlem yaparsak yapalım, tüm kuğuların beyaz olduğu sonucuna varmamız doğru olmaz (Popper, 2005:51-52)."

Popper tümevarımsal tekniğin yerine kavramların tümdengelimsel sınanmasını savunur. "Doğruluğu henüz savunulmamış ilk imge <Antizipation>, idea, varsayım ve kuramsal dizgeden mantıksal olarak tümdengelimle vargılar üretilir. Bu vargılar, kendi içlerinde ve diğer önermelerle, aralarında kurulan mantıksal ilişkilere (örneğin: eşdeğerlik, türetilebilirlik, bağdaştırılabilirlik, tutarsızlık) göre karşılaştırılır (Popper, 2005:56)."

Popper'ın bu görüşlerinden sonra viyana çevresi doğrulanabilirlik ilkesi yerine pekiştirme kavramını kullanmaya başlamıştır. Viyana çevresinin "anlam" problemi ile metafizik ile bilimsel olanı ayrıştırma gayretlerine karşılık Popper yanlışlanabilirlik ilkesi doğrultusunda mümkün olduğunca çok anlamlılıktan uzak durmak gerektiğini belirterek bunun yerine "sınır koyma" kavramı üzerinde durulması gerektiğini vurgulamıştır.

“Popper’a göre sınır-koyma bilimsel teorilerin bilimsel teorilerin temel özelliğidir. Çünkü her bilimsel teori birtakım olguları açıklarken birtakım olguları da kapsam dışında tutar. Yani bazı olguların bir teorinin çerçevesi içinde ele alınması yine aynı teori tarafından yasaklanır. Bilimsel bir teori ne kadar çok olguyu kapsamı dışında tutabiliyorsa, gücü de o oranda fazla demektir. Bilimsel teorilerin aksine sahte-bilimsel teoriler, hiçbir bilimsel sınıflandırma yapmadan geniş ve çeşitli olgu yığınını açıklamak amacı ve özelliğine sahiptirler. Hâlbuki bilimsel bir teoriye bakıldığında hangi olguların teorilerin kapsamı dışında kaldığını tespit etmek mümkündür (Popper, 1985:10)."

Popper, tümevarım konusunda Viyana çevresine yönelttiği eleştirilere karşılık insanoğlunun aslında bilgiyi teoriler üreterek elde ettiğinin tek tek deney ve gözlemlerden hareketle gerçek bilgiye ulaşılamayacağını savunur. Yani gözlem tek başına önem arz etmez. Tahminler aracılığı ile gerçek dünyanın dışında bir dünya oluştururuz ve gerçek bilgiye bu tahminler ve varsayımlar ile ulaşmaya çalışırız.

"Bilgi, realitenin bir kopyası, realiteden alınan bir izlenim değildir. Bilgi, genetik veya psikolojik olarak apriori'dir. Popper bu konuda Kant gibi düşünmekle birlikte, herhangi bir 
bilginin apriori geçerli olduğunu kabul etmenin yanlış olacağını söylemekle Kant’tan ayrılmaktadır (Popper, 1985:13)."

Popper bilimsel bilginin metafizik bilgiyle ilişkisi konusunda Viyana Çevresi düşünürlerinden farklı bir yaklaşım getirmiştir. "Eğer tüm deneyci gözlemler tahminlerle yüklü ise, bundan tahmin yürütme etkinliğinin bilimsel sürece zorunlulukla eşlik ettiği sonucunu çıkarabilir miyiz? veya "bilim" tahminleri formüle etme ayırcılı̆̆ını diğer etkinliklerle, örneğin metafizikle paylaşmakta mıdır?" (Boudouın, 1993:33).

Viyana çevresi anlam problemi ile bilimsel alanı metafizikten ayırmaya çalışmasına karşılık, Popper' a göre metafizik bilimin gelişim sürecinde önemli katkısı olan ve hakikat arayışında, bilginin zenginleşmesinde bilime etkisi olmuş bir alandır.

Popper' a Antik Yunan öncesi doğa olaylarını açıklamak için yapılan mitolojik açıklamaları da yadsınamaz. Çünkü o zaman için bu açıklamalar bir sorunu giderdiği için ve bir sonraki dönemde akli sorgulamaya olanak tanıdığı için gereklidir. İlk akli sorgulamalar Antik Yunan döneminde başladığı için Popper bu dönemi ayrıcalıklı tutar. Aydınlanma felsefesi de bir önceki dönemi sorgulama ve eleştirmeyle ortaya çıkmıştır. Bilimsel gelişim hep bir önceki döneme yanlışlama yoluyla bu güne dek gelmiştir. Her bir dönemde ortaya çıkan sorun yeni arayışlara yönelinmesini sağlamıştır. "Problem çözme ise biyolojik yaşamın ve ekolojik uyumun gerekli bir fonksiyonudur. İnsan yaşayabilmek ve gelişebilmek için sürekli olarak problem çözmek sorundadır. Zaten dil ve bilgi, doğal nedenlerden kaynaklanan problemleri çözme çabalarının bir fonksiyonu olarak gelişmiştir (Sunar, 1999:123)."

Popper’a göre bilimsel bilgi ile bilimsel olmayan bilginin ayrımı konusunda şöyle bir açıklama getirmektedir. "Popper, önce bilginin evrim sürecini şöyle açılamaktadır:

$\mathrm{P} 1 \rightarrow \mathrm{TS} \rightarrow \mathrm{EE} \rightarrow \mathrm{P} 2$. Burada P1 başlangıç noktasında karşılaşılan problemi, TS (trial solution) problemin çözülebilmesi için önerilen çözümü, EE (error elimination) daha önce yapılan yanlışlığın giderilmesini, P2 ise yeni bir problemin ortaya çıkmasını temsil etmektedirler. Bilgi, insanoğlunun yeryüzünde var olduğu günden buyana bu şekilde bir gelişme göstermektedir. Bu gelişme, belirttiğimiz gibi evrimsel uyumun (evolutionaly adaptation) bir fonksiyonudur. Daha öz bir deyişle doğal zorunlulukları aşabilmek için bilgiyi insanoğlu kendisi yaratır.

Fakat evrimin ilkel aşamasında, ilkel insan ilk bilgi niteliğini taşıyan gelenek ve göreneklerin, din ve mitolojinin yaratıcısının kendisi olduğunun bilincinde değildir. Illkel insan kendi yarattığı dünyaya yabancıdır, kendi yarattığı dünyayı kendi dışında var olan nesnel bir dünya sanmaktadır. Bu nedenle, ilkel insanın gelenek ve göreneklere karşı eleştirel bir tavır takınabilmesi söz konusu değildir; ilkel insan yaşamını temellendiren kültürel dünya dışında farklı dünyaların olabileceğini, farklı olasılıkların olabileceğini bilmez. Popper' a göre ilkel dönem eski Yunan düşüncesiyle, özellikle Sokrat ile son bulmuştur. Sokrat ve eski Yunan düşüncesi bilimselliğin temeli olan eleştiri ve eleştiri özgürlüğünü getirmiştir (Sunar, 1999:124-125)."

Popper'a göre Newton teorisinin yıkılması da bilimsel gelişime bağlı olarak eleştirel tavrın sonucudur. Her bir dönemin bir sonraki dönem tarafından sorgulanmaya başlaması gibi her 
önermenin ya da teorinin sorgulanmaya başlaması, bilimsel gelişimin o anki birikimiyle etkilidir. Sorgulanan teori yanlışlanır ve her yanlışlama bizi gerçeğe yaklaştırır. Ortaya atılan yeni teori yanlışlama ilkesine dayandığı için, gerçeğe bir adım daha yakın olduğu için daha üstündür.

"İşte Popper ile muhalifleri arasındaki anlaşmazlık bu noktada başlamaktadır: Bir teorinin diğerlerinden daha geniş kapsamlı olduğunu nasıl anlarız? Popper' a göre, bir teori yanlışlanabilene kadar geçerli sayılır; yanlışlandığı zaman başka bir teori onun yerini alır. Böylece, bilimde birikim teorinin doğrulanması biçiminde değil, yanlışlıkların ayıklanması şeklinde gerçekleşir. Ama yanlışlamadan sonra ne olur; bir teorinin diğerinden daha geniş kapsamlı olduğu nasıl anlaşılır? Popper bu soruları açık bırakmaktadır (Sunar, 1999:126)."

Popper, bilim adamının sarsılmaz doğrulara ulaşan yönünün olduğu kanısına katılmaz. Kesin mutlak doğrulara ulaşmak yerine mutlak doğru arayışının önemine vurgu yapar. Nihayet, Popper bilimde kesinlik arayışı idealinin sonunun geldiğini pek de üzüntü duymadan ilan eder; böylelikle bilimi, onu kuşatan bir dinsel saygıdan da arındırmış olur. "Yanlış bilim kavrayışı kendini kesinlik anlayışında ele verir. Çünkü bilim adamını var eden, onun doğruluğu çürütülemez bilgilere sahip olması değildir, ama ısrarla ve cesaretle hakikatin peşinde olmasıdır. Bilimci ve olgucu ağırlıklı kültürümüz, bilimde doğruluğu (tamlığı) bir tutmasına rağmen ve dilin gelişiminde "bilgi" veya "bilme" gibi terimlere hep kesinlik anlamını eşleşmiş olmasına rağmen Popper, kuşkuyu ve güvenilmezliği yeniden ön plana çıkarmıştır ve kuramlarımızın kutsanmak için değil yıkılmak için inşa edildiklerini, bilim adamlarının da kesinlik arayışını bilim anlayışından dışlamaları gerektiğini ilan etmiştir (Boudouın, 1993:41)."

\section{POPPER'IN ÜÇ DÜNYA KURAMI}

Popper'ın eleştirel tavrı neticesinde ileri sürmüş ve bilimsel bilginin özelliğini vurgulamak için üç dünya kuramını geliştirdiğini söyleyebiliriz.

- "Dünya 1, "fizik dünyadır, taşların, ağaçların, kimyanın ve biyolojinin dünyasıdır."

- Dünya 2, "Duyguların dünyasıdır, korkunun, umudun, eyleme koyulmanın ve her türlü öznel deneyimin dünyasıdır."

- Dünya 3 ise "insan zihninin dünyasıdır, düşüncelerin ve kuramların, ayrıca sanat yapıtlarının, ahlak değerlerinin, toplumsal kurumların dünyasıdır (Boudouın, 1993:16)."

Popper'ın bahsettiği üçüncü dünya insanoğlunun ürettiği tüm bilgi birikimidir.

Üçüncü dünya eleştirilebilir. Birinci ve ikinci dünyanın birdenbire yok olması insanlığa pek bir şey kaybettirmez ama üçüncü dünyanın yok olduğunu varsayarsak o zaman bugüne kadar bilgi adına tüm birikimleri yeniden inşa etmemiz gerekir.

"Bunu daha açık görebilmek için, insan soyunun yok olmasından sonra bizim birtakım uygarlaşmış ardıllarımızın (bunların uygarlaşmış dünya hayvanları mı ya da dış uzaydan gelmiş kimi ziyaretçiler mi olduğu hiç fark etmez) kimi kitapları ya da kütüphaneleri bulduğunu tasarlayabiliriz. Bu kitaplar çözülebilir... Bu, asıl bir nesneyi bir kitap yapanın ne 
düşünen hayvanlarca oluşturulması nede gerçekten okunup anlaşılması olmadığını; çözülebilir olmasının yeterli olduğunu epeyce açık kılar (Güzel, 1996:125)."

Bir başka deyişle insanların ortaya atmış olduğu teoriler, yine insanlar tarafından anlaşılıp eleştirme olanağına sahiptir. Bu teorileri tekrar test edip gözlemleyebiliriz hatta yeni teoriler üretebiliriz. Dolayısıyla bilgi insanın dışında nesnel bir olgu olarak vardır. Bu durum bilginin kamusal olduğunun göstergesidir. Her ne kadar bu bilgi alanını insan üretmiş ise de artık insandan bağımsız özerk bir hal almıştır. Popper bu durumu matematikten verdiği örnekle açıklar. "Doğal sayılar dizisinin insan yapısı olduğu konusunda Brouver'le aynı düşüncedeyim. Ama bu diziyi biz yaratsak da dizi kendi özerk sorunlarını yaratır. Tekle çift sayılar arasında ki ayrımı biz yaratmadık: bizim yaratımızın hem istenmedik hem de zorunlu bir sonucudur."

Popper’a göre üçüncü dünyanın özerkliği ve bünyesinde nesnelliği barındırması bilginin gelişiminde etkili olan en önemli özelliktir. Üçüncü dünyadaki etkileşimler O'na göre bilginin artışının en önemli nedenidir.

“Popper bütün bilimlerin bezer problemlerle uğraştığını belirterek doğal bilim- sosyal bilim ayrımı yapmamıştır. Temelde soyut düzeyde kalmak şartıyla toplumbilimlerinde de aynı yöntemlerin kullanılabileceğini savunur. Popper tarihin gelişim seyrini de kendine has üslupla şu şekilde açıklar. "Tarihsicilik eski bir düşüncedir, ya da daha doğrusu, gevşekçe birleştirilmiş bir düşünceler topluluğudur; ne yazık ki bizim manevi atmosferimizin, çoğucası tartışmasız kabul edilecek ve hakkında hemen hiç şüphe beslenmeyecek kadar bütünleşmiş bir parçası olmuştur (Popper, 2000:25)."

Popper' a göre tarihsel açıklamalar değişmez özellikler sahip yasalar değillerdir. Tarihi açıklamalar bakış açılarına göre yapılmış açıklamalardır. Popper' a göre tarihsicilik, seçilmiş halk öğretisiyle gözümüzde canlandırdığımızda, yazarı tanrı olan bir piyesin yeryüzünde oynanmasıyla tarihi anlama yolunda gösterilen gayrettir. Seçilmiş halk doktrini toplumsal yaşayışın kabile çağında ortaya çıkmıştır. Bu öğretide tarihsel gelişim yasasını Tanrı́nın iradesi tarafından şekillenmiştir. Modern döneme ait ise iki türlü tarihsicilik vardır.

1. Sağ yanda ırkçılığın ya da faşizmin tarih felsefesi

2. Sol yanda Markş̧ı tarih felsefesi (Inanç, 2018)

"Seçilmiş halkın yerine, ırkçılık, sonunda yeryüzünün kendisine kalacağı, kaderin aracı olarak belirlenen, seçilmiş, (yani Gabineau'nun seçtiği) ırkı koyar. Marx'ın tarih felsefesi ise, onun yerine sınıfsız toplumun yaradıışının arcı ve aynı zamanda yeryüzünün kendisine kalması alnına yazılı olan sınıfı getirir (Popper, 2000:26)."

Popper, sosyal teorilere dayanarak geleceğin inşa edilemeyeceğini savunur. Çünkü tarihsel gelişim insanlığın üretmiş olduğu bilginin etkisi altında kalır. Biz mevcut bilgimize dayanarak ve bilimsel metotları kullanarak gelecekten haber veremeyiz. Yani tarihsel önkestirimde bulunacak bir sosyal teoriden bahsetmemiz mümkün değildir. Eğer tarihsel önkestirimde bulunabilseydi, bunu bilen kişilerce hemen tarih müdahale edilirdi. Dolayısıyla tarih teorilerle asla şekillendirilemez. Sosyal realite tamamen teoriden farklıdır. 


\section{SONUÇ}

Aydınlanma felsefesi ile başlayan pozitif tutum fizikçi ve filozof E. Mach’ ın etkisiyle 20 yüzyıla gelindiğinde beklide en katı halini alma çabası içinde idi. Anglo- sakson deneyciliği ile Alman idealizminin birleştirilmesi gayreti, Viyana Çevresi' nin etkisi ile görünürde en belirgin sürecine girmişti. Karl R. Popper bu dönemde kendine özgü metotlarla düşüncelerini ortaya koymuş ve bilim felsefesine yeni bir boyut getirmiştir. Popper Viyana Çevresine karşı takındığı eleştirel tavırla, Çevrenin savunduğu doğrulanabilirlik ilkesine karşı yanlışlanabilirlik ilkesini ileri sürmüştür. Ayrıca, Hume' un ortaya attığı tümevarım sorununa beklide Popper'a kadar kayda değer çözüm getirilememiştir. Popper, bilimin tekil gözlemlerden kurama doğru ilerleme anlayışını değil, kuramın gözlemden önce olduğunu vurgulamıştır. Ona göre kuram veya mevcut teori bir şekilde vardır. Önemli olan bu kuramı sitemli bir şekilde yanlışlama gayreti içinde olmaktır. Bilimin asıl itici gücü bu yanlışlanabilirlik ilkesidir.

\section{KAYNAKÇA}

Baudouin, Jean (1993). Karl Popper, Çev: Bülent Gözkan, İstanbul: İletişim Yayınları, 1993.

Çelebi, Nilgün (1996). Sosyal Bilimlerde Yöntem, Konya: Aba\&Sebat Yayınları, 1996.

Denkel, Arda (1997). Düşünceler ve Gerçekler Felsefe Yazıları, İstanbul: Göçebe Yayınları, 1997.

Güzel, Cemal (1996). Sağduyu Filozofu: Popper, Ankara: Bilim ve Sanat Yayınları, 1996.

İnaç, Hüsamettin (2018). Faşizmin ve Sosyalizmin Sosyopolitik Kökenleri, İstanbul: Bilge Kültür Savat Yayınları.

Magee, Bryan (1982). Karl Popper'in Bilim Felsefesi ve Siyaset Kuramı, çev: Mete Tunçay, İstanbul: Remzi Kitapevi.

Popper, Karl R. (1985). Tarihselciliğin Sefaleti, Çev: Dr. Sabri Orman, Sunuş: Doç. Dr. Şafak Ural, İstanbul: İnsan Yayınları.

Popper, Karl R. (2000). Açık Toplum ve Düşmanları Cilt I, Çev: Mete Tunçay, 4.b., İstanbul: Remzi Kitapevi.

Popper, Karl R. (2005). Bilimsel Araştırmanın Mantığı, Çev: İlknur Aka ve İbrahim Tıran, 3.b., İstanbul: Yapı Kredi Yayınları.

Skirbekk, Gunnar ve Gilje, Nils. Antik Yunan'dan Modern Döneme Felsefe Tarihi, Çev: Emrullah Akbaş ve Şule Mutlu, İstanbul: Üniversite Kitapevi Yayınları, ( Tarih Belirtilmemiş).

Sunar, Illkay. Düşün ve Toplum, Ankara: Doruk Yayınları, 1999.

Tepe, Harun. Platon'dan Habermas'a Felsefede Doğruluk Ya da Hakikat, 2.b., Ankara: İmge Kitapevi, 2003. 